\title{
Tradition, Esotericism, Secrecy and Hiddenness in the Gospel Studies of P.D. Ouspensky and Maurice Nicoll
}

\author{
John Willmett \\ University of Edinburgh \\ jpwillmett@talktalk.net
}

\begin{abstract}
This article examines the views of Gurdjieff's disciples P.D. Ouspensky and Maurice Nicoll on the esoteric nature of the Gospels. Utilising one of Wouter Hanegraaff's definitions of esotericism as religious activity concerned predominantly with salvific knowledge of the 'inner mysteries of religion' reserved for a selected elite, Ouspensky's and Nicoll's view of the Gospels as the rendering in metaphorical form of esoteric knowledge as the formulation of the esoteric psychology of the path of inner evolution is discussed. Sources for this discussion are Ouspensky's A New Model of the Universe (1931), and Nicoll's The New Man (1950) and The Mark (1954). It is suggested that the Gospels render esoteric knowledge and its linguistic expression secret and hidden. Nicoll's idea of the necessity for this secrecy and hiddenness in dealing with the esoteric, that esoteric knowledge given to those unprepared for it is dangerous, both because it will be spoiled, its truth and beauty destroyed, and because it will turn into what Nicoll calls "world poison", is illustrated in a discussion of the thesis presented in Jacob Needleman's A Sense of the Cosmos (1975), that the rise of modern science represents an abuse of esoteric knowledge. The article concludes by presenting ideas from Needleman, Ouspensky and Nicoll of what needs to be done in the face of this current widespread abuse of esoteric knowledge.
\end{abstract}

\section{Keywords}

P.D. Ouspensky - Maurice Nicoll - hermeneutics - the "Fourth Way" - "Western Esotericism" - esotericism - Jacob Needleman 
In the chapter 'Christianity and the New Testament' in A New Model of the Universe (1931) Pyotr Demianovich Ouspensky (1882-1947), one of the closest collaborators with George Ivanovich Gurdjieff (c. 1866-1949), advocate of 'the Fourth Way', says: 'The Gospels tell directly and exactly of the existence of esoteric thought, and are themselves one of the chief literary evidences of its existence.' Ouspensky's pupil, assistant, and friend, Jungian analytical psychologist Maurice Nicoll (1884-1953), in The New Man (1950) and The Mark (1954) analyses the Gospels as vehicles for esoteric thought, both the substance of that thought and its esoterically hidden and metaphorically encrypted presentation. This article examines Ouspensky's and Nicoll's views of the Gospels as presenting esoteric knowledge in metaphorical and symbolic terms 'for the very few, for the pupils of an esoteric school'?

Wouter J. Hanegraaff ${ }^{3}$ classifies esotericism in two ways: historically and typologically. Viewed historically, esotericism is a label for specific Western cultural currents which Hanegraaff sees as having issued in what Antoine Faivre calls "Western Esotericism", a modern development of the Renaissance revival of Hermetic thought in broadly Neoplatonist terms. This current of thought evolved through Alchemy, Paracelsianism, the Kabbalah, Rosicrucianism, Christian Theosophy, and, in the nineteenth century, Madame Blavatsky's Theosophy. Ouspensky and Nicoll affirm the idea that the esoteric tradition of which they speak is part of a line of development common to all religions since time immemorial, an idea also found in the late nineteenth-century occult revival. It seems reasonable to see "the Work" and Ouspensky's and Nicoll's articulation of the role of the Gospels in it as belonging to those currents of traditions leading to "Western Esotericism". Nicoll's and Ouspensky's understanding of the Gospels represents, I suggest, a modern (and psychological) interpretation of age-old esoteric knowledge. In a similar vein Jacob Needleman, a noted Gurdjieffian (whose ideas will be examined later in the article), defines esotericism in Lost Christianity (1980) as 'the inner, spiritual content of the tradition of Christianity that works, that actually produces real change in human nature, real transformation: ${ }^{4}$

1 Ouspensky, A New Model of the Universe, 151.

2 Ouspensky, A New Model of the Universe, 149.

3 Hanegraaff et al., 'Esotericism', Dictionary of Gnosis and Western Esotericism, 336-340.

4 Needleman, Lost Christianity, 3-4. 
Typologically speaking, esotericism is, according to Hanegraaff, certain types of religious activity demonstrating the structural features of: 'the reservation of salvific knowledge for a selected elite of initiates; and a concern with the "inner mysteries of religion" as opposed to its "exoteric" dimensions. ${ }^{5}$ Formal structures limiting access to esoteric knowledge are not universal, and such strictures as were laid on Ouspensky and Nicoll were merely a discouragement from discussing "Work" ideas with those not in "the Work", and a ban on publication of their work. But in 1949 Gurdjieff changed his policy and "Work" ideas came before the general public in books published by Gurdjieff himself, Ouspensky and Nicoll. But though "the Work" enjoins no secrecy in the sense of the reservation of salvific knowledge for a selected elite, it most certainly is concerned with religion 'as an inner path', ${ }^{6}$ and is thereby esoteric in Hanegraaff's typological sense.

Equally important for the discussion is how 'reservation of salvific knowledge' is achieved through another mechanism alluded to by Hanegraaff, though not included in his definitive classification. Esoteric knowledge is, in documents, traditions, rites and so forth often couched in metaphor, image or symbol. This form of encryption draws a veil of secrecy over the text, which has to be drawn aside through hermeneutic interpretation before that text can be understood. While this procedure may have been a contrived obscuration of knowledge to reserve it for an initiated elite, this is only half the story, and the least important part. Hanegraaff cites Clement of Alexandria's observation that

disciples of Aristotle say that some of their treatises are esoteric, others common and exoteric. Further, those who instituted the mysteries, being philosophers, buried their doctrines in myths, so as not to be obvious to all. ${ }^{7}$

Though this burial of doctrines in myths may have been to reserve them for 'a mystic elite', its real purpose is different. Making doctrines into myths concerns, I suggest, the nature of the knowledge the doctrines embody, expressible only in symbolic form. Interpretation, though seemingly the circumvention of a protective barrier, is in reality a necessary exercise for learning to apprehend the truth encapsulated in the symbol. The initiate becomes such through developing the requisite hermeneutical skills to unravel the conundra hidden in the symbol.

5 Hanegraaff, 'Esotericism', 337.

6 Needleman, Lost Christianity, 18.

7 Hanegraaff, 'Esotericism', 356. 
Hanegraaff also cites Clement's Stromateis, which is usually translated as "miscellany", but the meaning of which is better conveyed as "odds and ends" or "rag-bag". Clement 'turned into myth' all sorts of things, leaving the reader to discover, through hermeneutical work, which items have value; some do not. This is secrecy through hiding valuable items amongst junk. James Webb questions whether Gurdjieff does similarly in his books, particularly Beelzebub's Tales to his Grandson (1950); ${ }^{8}$ this book, and almost everything that Gurdjieff wrote directly himself (rather than transcriptions of his lectures by others published in his name) are what can only be described as impenetrably arcane parables couched in an almost impenetrably arcane style seemingly full of convoluted nonsense, much of the content of which, it would seem, is indeed just that, as when Gurdjieff made up some word from the combination of two shop names he happened to be looking at (Dupichampo) to string the reader along, or talked about Parkt-dolg-duty meaning simply duty. ${ }^{9}$ Maybe this was done, to use Gurdjieff's metaphor, to "bury bone deeper so make dog dig for it", often to no avail; maybe it functioned instead as a trap to undermine the associative thinking of over-assiduous readers. ${ }^{10}$ Not all Gurdjieff writes is to be taken seriously. But when it comes to the Gospels, either when they handle esoteric ideas or metaphorical representations of the factual, they are never a Stromateis. As Ouspensky says, 'every phrase, every word contains hidden ideas'; ${ }^{11}$ there is no junk.

Turning doctrine into myth divides esoteric literature into two types. Much of what Ouspensky and Nicoll wrote is esoteric in that it has to do with the knowledge comprising 'the inner mysteries of religion'; but this is not presented esoterically in the form of myth, metaphor or symbol. When Gurdjieff, Ouspensky and Nicoll mention "Work" concepts like "essence", "real I", "hydrogens" and "self-remembering" they discuss these things in a prosaic manner. But Gurdjieff describing similar things uses esoteric formulations for them that require interpretation, and in Nicoll's Gospel exegesis doctrinal ideas, esoteric knowledge in themselves, are analysed esoterically as myths and symbols.

An extension of this idea is that while some of the religious images in the Gospels are allegorical figures, esoteric renderings of concepts that are in themselves doctrines or psychological or "Work" concepts reducible through hermeneutic interpretation to logically explicable concepts apprehensible by

Webb, The Harmonious Circle, 558. The full title of Gurdjieff's book is Beelzebub's Tales to his Grandson: All and Everything: First Series

9 Webb, The Harmonious Circle, 545.

10 Webb, The Harmonious Circle, 544.

11 Ouspensky, A New Model of the Universe, 15 . 
the ordinary mind, other images have a symbolic dimension irreducible in this way. Thus 'widow', a common scriptural image, stands for someone at a certain stage of spiritual development who has left behind the literal understanding of scripture and religion, seeing it figuratively. The widow in the story of the widow's mite [Luke 21:2, Mark 12:42], in which the minute contribution to charity that the widow makes but cannot really afford is characterised by Christ as an act of generosity that is worth more than that of the much more substantial contributions of 'rich men', stands for some not-further-identifiable act which in the world's eyes is of no significance when compared with equally not-further-identifiable acts that 'rich' (which certainly does not mean rich in the ordinary sense) men do. That "she" does it from herself (it is 'everything she possessed'), whereas "they" do it from what is not themselves (from superfluity), justifies "her" rather than them. In this perikope figures stand for facets of people's psychology; the parable might be read as a comparison within a single person. Though the presentation of the story is esoteric both in being metaphorical and in talking of the 'inner mysteries of religion', none of the figures or metaphors in it is a symbol; they are all hermeneutically reducible to logically apprehensible elements.

This mode of metaphorical interpretation is generally applicable to Christ's teaching when he does not use parables. But in teaching the parables, it is suggested, the non-reducible symbolic element comes to the fore in the hermeneutic process, transforming this from being decipherment of arbitrary commonplace figures into true interpretation of living symbols. Symbols have a power that figurative images or allegorical figures do not. Thus the six stone jars, the water and the wine of the Wedding Feast at Cana (John 2:1) may stand as figures for degrees of esoteric spiritual truth, ${ }^{12}$ metaphors graspable by the ordinary intellect; similarly, the figure of the 'master of the feast' is an allegorical figure standing for the ordinary personality, persona or ego. But the figures of Jesus Christ and his mother are symbols which carry un-analysable and ungraspable qualities, having a mantic power that even non-symbolic representations of them ("real I" or Anima, for instance) lack. The glory of the Gospels is that the psychology of the ordo salutis that "the Work" presents in figures drawn from psychology or science is there presented through living symbols.

As Ouspensky says, citing Oswald Wirth (1860-1943), Swiss occultist and interpreter of the Tarot, ${ }^{13}$ symbols reveal something from deep within; their effect comes from their resonance with the germs of the ideas they represent

\footnotetext{
12 Nicoll, The New Man, 14.

13 Ouspensky, A New Model of the Universe, 219.
} 
already present in ourselves. Their coming forth is the revelation, the unveiling from deep within the psyche of 'something proceeding immediately from the higher consciousness or from higher powers.' ${ }^{14}$ No mere image, concept, or allegorical figure, can bring this about. ${ }^{15}$ Therefore (to return to the Wedding at Cana) if we have esoteric truth in us, stone, water and wine will function as symbols; if we have Christ in us He also will so function. These symbols show us esoterically something true about ourselves but unknowable to the ordinary senses. As René Guenon says, knowledge gained from reading symbols is what metaphysics properly understood is concerned with, knowledge that is in a certain sense supernatural (meta, beyond, and physis, sensory nature). This knowledge is of a higher order than purely human or rational knowledge and is esoteric in being inapprehensible by the ordinary intellect. It is obtainable only by the strictly personal effort of forming a higher mind in oneself, and thus hidden from those without this higher mind.$^{16}$ Needleman says that, as only like can know like, we have to be symbols ourselves by being transformed on to the level of microcosmic man before we can have the higher mind, the developed "intellect" to understand those symbolic entities that, more than mere rational thoughts, are true ideas. 'Symbolic understanding is a process which can only take place to an extent that the knower is himself a moving symbol, a microcosm. ${ }^{17}$

In analysing the work of Ouspensky and Nicoll I will therefore focus: on Ouspensky's ideas on the place of the Gospels in the history of the esoteric tradition (A New Model of the Universe); on 'the Work' as ordo salutis, a description in practical psychological terms of the progress of the esoteric 'inner mysteries of religion' in a person's psychological evolution, described both by Ouspensky (in A New Model of the Universe) and by Nicoll in his compendious collection of the lectures that he delivered at his meetings, collected together as Commentaries on the Teachings of G.I. Gurdjieff and P.D. Ouspensky; and on Nicoll's view of the Gospels as the expression of this same ordo salutis in esoteric psychological, religious, allegorical and symbolic images as presented in his 'exegetical' works The New Man and The Mark.

\footnotetext{
14 Ouspensky, A New Model of the Universe, 34.

15 Ouspensky, A New Model of the Universe, 202-210 passim.

16 Guénon, 'Oriental Metaphysics' in Needleman (ed.) The Sword of Gnosis, 40-56, 42-43.

17 Needleman, $A$ Sense of the Cosmos, 85 .
} 
Ouspensky sees the canonical Christian Gospels as universal documents of extraordinary power; every phrase in them, every word, contains hidden or esoteric ideas, and when one brings these hidden ideas to light the power and influence of the Gospels, over almost two thousand years, becomes clear. In distinction to the Epistles, the 'founding documents' for the 'building of the Church' containing advice on the application of esoteric thought in the body of that Church, the Gospels were written for the very few, for pupils of esoteric schools, not the simple but those with a degree of understanding who possess a key, who, beginning with Church Christianity (Pauline Christianity), but capable of understanding the esoteric idea can come into touch with the first source and perhaps succeed independently in finding the hidden truth. ${ }^{18}$ Thus, though the appeal of the Gospels is universal, in that they seem to offer esoteric knowledge to the many, this knowledge is in reality, in Ouspensky's view, open only to the few.

The clue to this conundrum is the esoteric nature of the Gospels, the texts of which, Ouspensky says, have been corrupted by theologians for their own purposes. Not historical fact, or biography, but myth, the Gospel texts are not evidence of the events of 'the Drama of Christ'. The 'events' of this 'drama', the virgin birth, Christ's being the Son of God, the Mystery drama of the crucifixion and Christ's voluntary sacrifice are Indian, Buddhist, Old Testament or Greek myths, incorporated into and developed in the texts after these were "originally" written. ${ }^{19}$ Many people, however, unable to understand the mythological nature of the Gospels, having no idea of esoteric thought, take from Christ's teaching only entirely false ideas, and to them Christ has nothing to say. ${ }^{20}$

In its true meaning Christianity is, in Ouspensky's view, a stern religion, infinitely removed from the sentimental Christianity of modern preachers. That salvation will come to few, and only with much difficulty, is definitely and frequently emphasised in the Gospels. It is therefore only the lies and hypocrisy of modern Christianity, presenting the far-from-true idea of Christ being some sort of social reformer, and the narrow sectarian ideas of post-mortem rewards and punishment of the religion of 'Hell-and-Sin' that can convince people that the Gospels offer 'general salvation'. The purpose of the Gospels, however, is

18 Ouspensky, A New Model of the Universe, 149, 15 .

19 Ouspensky, A New Model of the Universe, 157.

20 Ouspensky, A New Model of the Universe, 206. 
to show people that there is 'only one way to hidden or esoteric knowledge, to show this to those who can follow it and to make a selection of those fit for it, to divide people into suitable and unsuitable, from this point of view'. ${ }^{21}$

Ouspensky offers his own esoterically-informed exegesis to show how hidden knowledge is presented in the Gospels. He says that only those 'poor in spirit' [Matthew 5:3], that is, those who practise the 'Buddhist idea of nonattachment to things' can embrace the Kingdom of Heaven. The change of attitude demanded to achieve this, metanoia, (which, as Nicoll is never tired of pointing out, means a turning around of the person, a change of attitude, but not repentance \{as in 'Repent for the Kingdom of Heaven is at hand' [Matthew 3:2]\} repentance being a mistranslation of this Greek word used here) makes such people hated by the world and persecuted, particularly by 'pseudo-Christians', for their endeavours to preserve esoteric truths in the midst of a church Christianity become distorted. These people should 'not cast pearls before swine' [Matthew 7:6-meaning force esoteric teaching on those unable to understand it, an interpretation affirmed by both Ouspensky and Nicoll] but keep silence, knowing they will always be in that minority who, not expecting earthly blessings, earnestly seek esotericism, which is 'life' [Matt 18:19, 19:17]. The parable of the sower [Matthew 13:1-23, Mark 3:1-20, Luke 8:4-15] referring to esoteric ideas understood only by a very few, is framed to exclude those without 'ears to hear' [Matthew 11:15, but the phrase is used frequently in both Old and New Testaments], this being the purpose of this way of teaching. Standing in the way of metanoia is 'riches' [Mark 10:24], not literally money, wealth or worldly position, but, esoterically or metaphorically expressed, the opposite of poverty of spirit, that is, identification and self-satisfaction with the worldly personality. Unless a man dies to the riches that are the world and himself, the seed in him, symbolised by either the mustard seed [Matthew 17:20] or the seed the sower sows, cannot grow. ${ }^{22}$

Though all are called to metanoia (change of heart/ transformation of mind), most are held by life. These latter, considered from the point of view of esotericism 'dead' (not of course physically dead, but spiritually), renounce the chance to be born again, thereby sacrificing great possibilities for the sake of the little present. Such people are 'Pharisees and hypocrites' [Matthew 23:27], not the historical doctors of the law, but people, or parts of us 'without the idea of esotericism', who, their life regarded as 'death', are 'as graves' [Luke 11:44]. Pharisees, called in the Gospels, Ouspensky says, 'tombs' and 'the blind', are

21 Ouspensky, A New Model of the Universe, 148-152 passim.

22 Ouspensky, A New Model of the Universe, 166-168 passim. 
'whitened sepulchres' [Matthew 23:27], their morality only outward pretence. Unless the seed of our life dies by our abandoning that life which appears beautiful outwardly, but is within full of dead men's bones, it cannot grow into the great tree of eternal life. ${ }^{23}$

To heed the call and become disciples requires a special 'watchfulness'. One aspect of this, which Ouspensky (his italics) says came from Buddhism is encapsulated in the command to the cleansed leper who returned to thank Jesus to 'tell no man' [Matthew 8:4-Ouspensky's italics]. "Initiated" converts must not boast to non-initiates about things esoteric but work in secret: 'do not your alms before men' [Matthew 6:1]. Though the sacrifice will be worth it, disciples must obey the law, being even more meticulous towards their brother (fellow convert), becoming 'perfect' (teleios, meaning perfected or completed, not a moral description) as described in the "Sermon on the Mount" [Matthew 5:48]. But this "Sermon", a special, complex and practical teaching, constitutes an occult or esoteric system of self-training based on principles unknown outside occult schools, according to Ouspensky. Similarly, the Lord's Prayer [Matthew 6:9-15], a petition for purely spiritual things, is not a general prayer; it is intended only for those disciples who, achieving the awareness that makes the commands of the Sermon on the Mount a practical possibility, can, since Christ did not preach impracticable things, carry them out. ${ }^{24}$

There is a hierarchy in the Kingdom of Heaven, which is neither a worldly regime nor a post-mortem millenarian paradise, but a spiritual state attainable in the here and now. No one who aspires to it must think himself superior but be the servant of all. This does not mean servant in a worldly way of 'any man', as in 'sentimental Christianity', but means to be a 'neighbour', who, from Ouspensky's esoterically determined point of view is one who helps someone to know esoteric truths and approach esoteric work. Pharisees, the opposite of neighbours, thwart those seeking esoteric understanding ('little ones'), causing them 'offence' (a metaphor for the distortion of esoteric truths). ${ }^{25}$ Distorting and adapting everything into a pseudo-religion, unable to understand the truth in esoteric or metaphorical terms and taking everything in the Gospels literally, they lead people astray, preventing them entering the Kingdom of Heaven. ${ }^{26}$

23 Ouspensky, A New Model of the Universe, 174, 180-181.

24 Ouspensky, A New Model of the Universe, 182, 192, 194.

25 Ouspensky, A New Model of the Universe, 200.

26 Ouspensky, A New Model of the Universe, 196-20o passim. 
Ouspensky's view of the Gospels is that they are esoteric documents intended for members of the Pauline Church ${ }^{27}$ who wished to proceed further within the constraints of belonging to an esoteric group with the process of inner transformation described in them. The Gospels describe in symbolic terms the esoteric process of inner transformation which, while not for all, is not beyond people's capabilities. The Gospels exhort a strictly practical training in all details: 'it is practical first of all because it is not for all'. Those who undergo this training, separate from the mass of humanity, possess esoteric knowledge that is inaccessible by ordinary thinking and may thus be considered hidden or secret. Initiates possessing this knowledge have the Kingdom of Heaven, or eternal life. ${ }^{28}$

\section{Nicoll's View of the Gospels}

Nicoll, when he first became Ouspensky's pupil, was so alienated from the Christian Church that Ouspensky's ideas on the Gospels initially had little meaning for him. Nevertheless, he was impressed at how many versions of the New Testament Ouspensky owned. Soon Nicoll was involved in the editorial process of A New Model of the Universe, and doubtless the New Testament and its relationship to "the Work" were discussed in meetings. The outcome was that Nicoll's views on the Gospels came to mirror Ouspensky's, more or less exactly. Nicoll aligns himself with Ouspenksy's ideas about the place of the teaching of the Gospels in the perennial tradition when he says:

Behind all the rising and setting external forms of religion there has been a broad, fully-developed stream of knowledge, always the same and always having the same object—namely, the quickening and inner growth and evolution of Man to a higher level in himself. ${ }^{29}$

27 I take Ouspensky's frequent mention of St Paul's Church to mean that he understood that St Paul's Christianity was primitive and foundational ['the Church, which in fact originates from the Epistles'—Ouspensky A New Model of the Universe, 149]. This Church only later came to see the need to write esoteric documents based on the 'life' of Jesus which receives no mention in Paul's writings, where Iesous Christos is a spiritual or psychological presence only ('the chief role was played by the understanding of the Gospels based not on Christ, but on Paul', 149). This is my interpretation of Ouspensky's idea.

28 Ouspensky, A New Model of the Universe, 206.

29 Nicoll, The New Man, 82. 
Nicoll characterises the Gospels themselves as documents describing the psychological training of the inner person needed for self-evolution; they are thus a systematic description in metaphorical or symbolic terms of an ordo salutis.

The Gospels speak mainly of a possible inner evolution called "re-birth". This is their central idea. They are from beginning to end about this possible self-evolution. They are psychological documents. ${ }^{30}$

The Gospels present in Nicoll's view esoteric knowledge of 'the inner mysteries of religion', what Needleman calls 'Christianity as an inner path', ${ }^{31}$ a path to some higher or more fully-developed inner state of psychological selfevolution. A description of this path, and how it is rendered in the metaphorical and symbolic images of the Gospels, is set out in Nicoll's books, The New Man and The Mark. Starting with the great cry to metanoia, 'Repent, for the Kingdom of heaven is at hand', and understanding that, as already mentioned, 'repent' is a mistranslation of metanoia, which properly means "see things in a different light", "change your mind about things", "be of a different mind", having not the slightest idea of penitence or remorse about it, ${ }^{32}$ Nicoll says that the Gospels call first for a kind of purification to lift a person out of the world on to a higher plane. John the Baptist is a figure for this purified outer person that nevertheless has to be sacrificed so that the higher person, symbolised by Christ, can increase while it decreases. This purification, more of mind than morals, brings about faith, the faith which is not mere belief but the formation of a higher mind that gives evidence to the inner person of things not apprehensible by the ordinary mind. Nicoll would agree with Ouspensky in interpreting the faith talked about in Hebrews 10:1, 'faith is the evidence of things not seen', as awareness or real experience, not belief in a later sense, which however cannot be apprehended by the senses. Faith thus brings about an awareness of a higher level in a person, and makes clear that submission to this higher level is necessary. ${ }^{33}$

The Sermon on the Mount [Matthew $5^{-6}$ ] describes the necessary psychological reform for the next stage of self-evolution after metanoia, re-birth. Blessed [Greek makarios] means 'given force from Heaven'. ${ }^{34}$ The beatitudes

$30 \quad$ Nicoll, The New Man, $3,4$.

$31 \quad$ Needleman, Lost Christianity, 18.

$32 \quad$ Nicoll, The Mark, 93, 94, 97, 98.

33 Nicoll, The New Man, 93-94, 124-127.

34 Mounce, Complete Expository Dictionary of the Old and New Testaments, 7o, has 'the individual who receives divine favour'. 
describe the psychological qualities needed to be in receipt of this force. The poor in spirit (for Ouspensky someone detached from the world in the Buddhist sense) is someone who mourns the death of the outer personality, is submissive (meek, Greek praos, means tamed, lacking in resentment), and is hungry for what will replace what they imagined had made up their life before. Such a person, inheriting the Kingdom of Heaven and the Earth, receiving this force, will be comforted and filled. The person who shows mercy, who forgives, will be forgiven; those who purify their heart will see God; having made away with hypocrisy they are aware of higher levels in themselves to which they submit in faith. The blessed, who receive this force from Heaven will know the 'peace that passeth all understanding', though this is not external, since these blessed people, hated by the world, will be persecuted, especially by those that Ouspensky calls pseudo-Christians who think that they do God's work. ${ }^{35}$

Equally esoteric and psychological are the exhortations found in the second part of the Sermon. Loving your enemies means forgiving all, whether they have sinned against you or not, in the process seeing where your own fault in the situation lies, of seeing others in yourself, and yourself in others, this bringing an increase in consciousness and a further confrontation with your negative side. Turning the other cheek refers to confronting forces, thoughts and feelings that assail everyone in life, but without succumbing to them, in a kind of psychological judo that involves taking a step back before reacting in a considered way. Needleman suggests that this technique lies at the root of the recommendations in the Pratikos of Evagrius Ponticus, the fourth-century desert father who first formulated the seven deadly sins. Evagrius exhorts us not to let thoughts and feelings turn into emotions, that is, 'passions.' ${ }^{36}$ I have argued elsewhere ${ }^{37}$ that I understand turning the other cheek to mean the struggle that Needleman describes, a struggle against egoistic emotions in that exact "space" before a thought, impulse or association becomes an emotion. This battle, which according to Evagrius, Nicoll and Needleman must be lifelong, builds in a person 'purity of heart' (Evagrius uses this term frequently) and the state of apatheia, which is freedom from domination by the emotions. This confrontation is equivalent to Gurdjieff's "self-remembering". "Self-remembering" is a constant battle against 'negative emotions' (Evagrius' passions) and against "identification" with the nexus of these emotions that forms the ego, making a person driven by passions. Nicoll therefore sees the Sermon on the Mount not as a universally applicable moral code governing interpersonal relations, but

35 Nicoll, The New Man, 93-103.

$36 \quad$ Needleman, Lost Christianity, $136 f f$.

37 Willmett, Maurice Nicoll and the Kingdom of Heaven, 192. 
as a series of technically precise psychological exercises intended for members of an esoteric school, which, though worked out in ordinary life is undertaken at one particular point along the path of inner self-evolution specifically for mastering the egoistic emotions.

Someone 'pure of heart' who has passed through this process will have a higher type of mind, 'a new mind, another kind of thinking'. 38 The idea of this new kind of mind is presented esoterically in the parable of the wineskins [Luke 5:36-39]. Those from whom the truth of Christ is hidden, the Pharisees, take Christ to task for allowing his disciples to 'eat and drink' while John the Baptist's disciples fast. Christ, saying they have the wrong idea, that what he teaches concerns understanding, not ascesis, says that while the bridegroom is present (this refers to the inner marriage, a symbol for the Kingdom of Heaven and the path to reach it, of which Christ is the supreme symbol) the guests must eat and drink, but that to drink the new wine of this new teaching a new mind is needed. If the old mind is used it will burst like an old wine skin, spoiling the teaching [Luke 5:37]. ${ }^{39}$ The 'lowest level of the mind must not be used for ideas not derived from the senses'. ${ }^{40}$ The puzzlement of the Pharisees represents the withholding of esoteric knowledge both to protect the Pharisees, whose minds will burst if they try to understand this new teaching with the ordinary mind, and to protect the knowledge itself, which will run away and be spoiled unless understood by those with the necessary understanding, those of whom the parables say 'he who has ears to hear, let him hear'. Although the idea of the Sermon on the Mount as a series of exercises has by now long been lost in a sea of sentimental reverence for some kind of "New Testament ethic", both Ouspensky and Nicoll emphasise that this teaching is for initiates only, that 'on the Mount' refers to those who have ascended the mountain that is the path of inner evolution. But if the truth falls on the mind unprepared for it, what Nicoll calls 'world poison' is created.

Nicoll sees Christ's teaching in parables as an abrupt change in the nature of his ministry. ${ }^{41}$ This change, it is suggested, is a metaphor for the idea that the truth the parables contain lies at a higher level in a person, and that it concerns a later stage of the ordo salutis. Christ teaches his first parable from a boat, that is from a level above that of the world. At this stage the teaching becomes delib-

38 Nicoll, The Mark, 12, his italics.

39 Nicoll, The New Man, 37.

$40 \quad$ Nicoll, The New Man, 56.

41 'In the thirteenth chapter of Matthew, Christ begins to speak in parables to the multitude. Why? Because he is beginning to speak of the Kingdom of God. His disciples ask him why he has suddenly begun to use parables ...' Nicoll The New Man, 153 . 
erately esoteric in nature. Ideas in the parables are overtly figurative and require interpretation. Nicoll says they convey teaching about the Kingdom of Heaven, which he sees as the next and third stage in the progression metanoia, re-birth and the Kingdom of Heaven. ${ }^{42}$ Knowledge of this state can only be conveyed symbolically and requires an equivalent awareness in the listener.

The esoteric nature of the parables is according to Nicoll a form of secrecy. He suggests that the parables were deliberately constructed to exclude those unable to understand, those without 'ears to hear'. He cites Matthew's quotation of Isaiah 6:9-10 which occurs at this point in the narrative:

I speak to them in parables, because they, seeing, see not, hearing, hear not, neither do they understand, lest they should see with their eyes, hear with their ears, understand with their hearts, and be converted, and I should heal them [Matthew 13:13-15].

Nicoll's interpretation is that by teaching in parables Christ is deliberately further restricting his teaching to the initiated.

The first parable in Matthew's Gospel, the Sower, is presented as the key to all the others. It concerns 'categories of men in their relationship to esoteric ideasthose who cannot understand them, those who understand them wrongly and those who understand them and follow them. ${ }^{43}$ The image of the Kingdom of Heaven in this parable is of fruit that grows, or seed that grows into fruit, that seed being man himself. The Kingdom of Heaven is the growing and ripening of this fruit. This, just one esoteric image of the Kingdom of Heaven, is similar to: the woman who places leaven in the meal; and the mustard seed. Other images used are of something hidden (in oneself) and found: the merchant who bought the pearl of great price; the man who buys the field in which is hidden treasure; the lost coin; and most famously the lost sheep. ${ }^{44}$ Perhaps the most significant parable of this lost-and-found type, however, is that of the prodigal son [Luke 15:11-32], a classic story of palingenesis which combines the ideas of something lost and found with two other images of the Kingdom of Heaven found in the Synoptic Gospels, the feast, and a journey away and a return. Sometimes the feast is a wedding feast, or the return is of the absent landlord. The Gospel of John, stemming from a different tradition from that of the Synoptic Gospels has no parables as understood there, but in The New Man, the sub-title of which is An Interpretation of some Parables and Miracles

42 Nicoll, The New Man, 135.

43 Nicoll, The New Man, 55.

44 Matthew 13:45-46; Matthew 13:44; Luke 15:8-10; Matthew 18:12-14 and Luke 15:3-7. 
of Christ, Nicoll treats a number of perikopes from John's Gospel as parables. In John's Gospel the Kingdom of Heaven is depicted as the inner marriage, as in the Wedding at Cana, and as fish caught in a net. The raising of Lazarus, of undoubted Egyptian provenance, shows the motif of the dying and rising God in its simplest form. The crucifixion and the resurrection is another image of the Kingdom of Heaven, found in all the Gospels, as well as in Paul's letters, where also the images of the casting off of the Old Man and the putting on of the New Man (to which Nicoll's book title alludes), and the birth of the 'Christ in us' are found.

For Nicoll all these images of the Kingdom of Heaven are esoteric formulations of the idea of the growth of understanding in the inner invisible life of a person;

to become a more understanding person is a psychological development. It lies in the realm of the thoughts, the feelings, the actions, and, in short, the understanding. A man is his understanding. If you wish to see what a man $i s$, and not what he is like, look at the level of his understanding. ${ }^{45}$

But although Nicoll does not mention "the Work" in either The New Man or The Mark, his idea of the reality of the Kingdom of Heaven born in or built in the person is the same as Gurdjieff's. The harmonisation of the three centres (moving, emotional and intellectual) causes "Essence" to grow in a person, and the "real I" is realised in a process of increasing consciousness. The formation of real I, an esoteric idea in itself, is the equivalent of building the second and higher bodies in a person, the return of the master (charioteer) to the chariot, and the building of the immortal soul in a person. This is the Kingdom of Heaven. The Gospels are therefore, in Nicoll's view, descriptions of the way to achieve this state in oneself. They contain esoteric knowledge, or knowledge of esoteric matters couched in the form of myth and symbol which needs to be interpreted.

Nowadays figurative understanding of Scripture is frowned upon. "Fundamentalists" hold to the inerrancy of the Bible understood in literal terms. But Nicoll asks why esoteric knowledge has to be presented figuratively in parables, myths 
and symbols, why it cannot be given directly? By saying that everyone has two sides, outer and inner, Nicoll sees esoteric knowledge as the only knowledge pertinent to and apprehensible purely by the inner nature, from which alone the esoteric language that conveys esoteric knowledge can be understood. This esoteric language, Nicoll informs us, 'an ancient language, cast in the form of ancient meaning now forgotten', ${ }^{46}$ was once well understood, and was used by the Gospel writers to discuss esoteric matters. The terms of this language have a double meaning, higher and lower. The surface of the parable, the ordinary meaning the words bear conveys a graspable image to the listener, but the real meaning is conveyed through the higher meaning of the symbol. Thus, in the parable of the wine skins, where wine means spiritual truth, and a wine skin (like most containers, goblets, cups, and so on) stands for the mind, the dramatic image of the bursting wine skins conveys the idea of failure to understand. In Nicoll's view all parables work in this way, and their meaning can only be divined by a person with a sufficiently developed mind, with 'ears to hear'. But the difficulties of hermeneutic analysis, far from being a barrier, function for those with ears to hear as the means of unravelling the mystery contained in the text. As Robert Segal has said: 'the obstacles that modernity poses to a literal rendition of Christ's life offer an opportunity to make clear for the first time the meaning intended from the outset'. ${ }^{47}$ Nicoll writes:

It is more than interesting to read again the scattered fragments of Christ's teaching present in the Four Gospels and pick out what was really meant, in the light of the Work. Nothing is more releasing for the fast-bound religious mind that holds many in prison—yes—now—at this moment. ${ }^{48}$

The effort of picking out the meaning, of making clear for the first time the meaning of this knowledge is a form of initiation.

The second reason for the hiding of the meaning of esoteric knowledge behind an esoteric formulation is to protect both the unprepared listener and the knowledge itself from the dangerous consequences of misunderstanding the symbols. In his exegesis of the Sermon on the Mount Nicoll analyses the symbolism of salt; we should become 'the salt of the earth'. In salt, compounded of sodium and chlorine, the sodium in a person stands for 'the good ground, of

46 Nicoll, The New Man, 6.

47 Segal, 'Myth and Ritual', in John Hinnells (ed.), The Routledge Companion to the Study of Religion, 74 .

48 Nicoll, Commentaries, 1223. 
which the Gospels so often speak', in which the seed will grow into the fruit that is the Kingdom of Heaven. Chlorine stands for higher knowledge a man receives from outside himself'. The process of entering the Kingdom of Heaven is seen by Nicoll as an inner 'marriage of the two things which constitute the whole of his inner life', symbolised as the conjunction of sodium and chlorine using a metaphor from chemistry that could not possibly have been known in biblical times, but which seems peculiarly apt. ${ }^{49}$ Chlorine, that is esoteric knowledge, will, should there not be enough sodium to absorb it, poison a person and 'may simply produce world poison'.$^{50}$ Esoteric knowledge cannot be understood without a corresponding development of being. In certain situations, the acquisition of esoteric knowledge by people unfitted to understand it can only produce the worst results. Such knowledge is misunderstood, and likely to be misused.

It might be objected that all this is rather quaint and un-worldly. What does it matter if ill-prepared people use esoteric knowledge for purposes other than those originally intended? Why is it so catastrophic if the esoteric safeguard that the metaphorical representation of knowledge affords fails to protect it and those unfortunates who misunderstand it? Why did the ancients understand that "the reception of each new idea required special preparation, since an idea caught in passing can easily be seen in a wrong light, or received in a wrong way, and that a wrongly received idea can produce very undesirable and even disastrous results"? ${ }^{51}$ What is the nature of this world poison that Nicoll says will issue from the misunderstanding of knowledge acquired without the necessary level of being to support it? I refer in the first instance to Needleman's A Sense of the Cosmos, and then to his compilation The Sword of Gnosis, particularly the essay 'Cosmology and Modern Science' by Titus Burckhardt, to suggest that esoteric knowledge misused has had profound unfortunate consequences for the world on the widest scale. Not merely misunderstood and thus unable to perform its salvific work it has become all-too-effectively malign.

Needleman employs the rise of modern western science to show how this is so. Suggesting that science grew from the Renaissance revival of Hermeticism

49 Nicoll, The New Man, 102.

5o Nicoll, The New Man, 36 .

$5^{1} \quad$ Ouspensky, A New Model of the Universe, 135-136. 
and alchemy, Needleman says that these two arcane disciplines were expressions of what he calls 'the sacred science', the path or the way (Needleman's italics), what we would call in terms of this article the esoteric tradition of religion as an inner path. Esoteric both in being open, initially at least, only to initiates or adepts, esoteric also in that the literature of both alchemy and Hermeticism is arcane in the extreme, these arcane disciplines were pursued by "brotherhoods of seekers" seeking to attain transformation of the inner person or the soul through interpreting this literature. There were, of course, those among the practitioners who did not understand what they were doing; these, in the case of alchemists, were known as "charcoal burners". But from the practices of both those who did and did not understand what they were about arose the modern sciences, in the case of alchemy modern chemistry. Something essential and scientifically understandable and verifiable was discovered from metallurgical processes originally intended as a mere cover for psychological or spiritual procedures. Needleman's point, however, is that the rise of science stems from a misunderstanding of arcane disciplines of the path, from the infringement of esoteric secrecy. While science was in some way a breakthrough, affording people freedom from the isolated thought association and mere speculation that medieval scholasticism had become, in the process the ideas of the arcane disciplines, properly nurtured and relevant only within the discipline of the path were forced by those having no concept of the path or way to serve a completely different function from that originally intended. Esoteric ideas that, anchored in the discipline of the path were intended to lead to a unity of mind and body that elevated body to parity with mind as an instrument of knowledge, were abused to yield abstract concepts that served only to unify in the rational mind external facts about the material universe by functioning as the theories and hypotheses of rational science.

Needleman justifies and expands this view by examining a number of the scientific hypotheses that have had a crucial impact on modern life, particularly: the replacement of the Ptolemaic view of the cosmos, the so-called geocentric view by Galileo's heliocentric view; Darwin's idea of evolution through natural selection; the psychoanalytical movement; and the 'New Physics' that followed the discoveries of Einstein, Planck and Heisenberg. Needleman's thesis is that the ideas that issued in these modern scientific disciplines were, rather than mere rational thoughts, all true ideas (Needleman's italics), that is, esoteric knowledge the purpose of which was to lead to the unification in people of body, heart and mind at a higher "intellectual" level. These ideas surfaced at a time when the ancient formulations of truth that the major religions are, truth that should have had the same purpose of giving inner unity in a person, were failing. But though "meant to help people discover the truth 
for themselves, [these new truths] become instead mere tranquillisers or even forms of psychological poison." ${ }^{.52}$ The Ptolemaic view of the universe probably never existed in the ancient word as purely external literal "geocentrism" but was '“a parable spoken to the multitudes?", 53 a truth, anchored in the religions, not scientific, but in which 'all is contained definitely in our own soul, whose lower ramifications are identified with the realm of the senses, but whose root reaches up to the pure being and supreme essence, so that man grasps in himself the axis of the cosmos. ${ }^{54}$ 'The concentric spheres that encircle the earth in the Ptolemaic view represent superior states of consciousness and more exactly the modalities of the soul that, while still contained in the integral individuality, are more and more irradiated by the divine spirit'. 55

Though suggesting that Dante, in The Divine Comedy, making a journey that transcended this limited "world" (whether that be simply the corporeal world, or the lower ramifications of the soul identified with the realms of the senses), paints a picture of a fusion of it and the subtle world, this latter 'incomparably vaster and more varied than the corporeal world, ${ }^{56}$ obtaining thereby a new vision of God as a sun at the centre, but this a metaphor for 'the unplumbed complexity of the human soul', rather than any physical cosmos, ${ }^{57}$ Burkhardt sees that neither of the orders of Ptolemy or Dante is a literal representation of cosmography, but each a cosmology that gives man a view of his central organic place in the universe congruent with his subjective experience. But when Copernicus (followed by Galileo) in "a dangerous popularisation of an esoteric truth" 58 rather than producing 'a new spiritual vision of the world'59 misunderstood Dante's esoteric vision as literally real cosmography, this destroyed people's feeling of centrality, banishing them to the margins of the universe where, as Nicoll says, they became only a 'measurable quantity of matter in the universe of matter and are ruled out of the picture' ${ }^{60}$ Galileo's scientific heliocentric view (though not of the universe, as was Dante's, but only of the solar system) was thus a fortuitous, scientifically fruitful exoteric misunderstanding of Dante's esoteric "reflection of the superior order" which, though turning out

$5^{2} \quad$ Needleman, $A$ Sense of the Cosmos, 7.

53 Needleman, $A$ Sense of the Cosmos, 26.

54 Burkhardt, 'Cosmology and Modern Science' in Needleman (ed) The Sword of Gnosis, 124.

55 Burkhardt, 'Cosmology and Modern Science' in Needleman (ed) The Sword of Gnosis, 124, 126.

56 Burkhardt, 'Cosmology and Modern Science' in Needleman (ed) The Sword of Gnosis, 164.

57 Burkhardt, 'Cosmology and Modern Science' in Needleman (ed) The Sword of Gnosis, 164.

58 Burkhardt, 'Cosmology and Modern Science' in Needleman (ed) The Sword of Gnosis, 127.

59 Burkhardt, 'Cosmology and Modern Science' in Needleman (ed) The Sword of Gnosis, 127.

6o Nicoll, Living Time, 12. 
to be 'true' scientifically had, when taken literally rather than esoterically by those with minds unprepared for it "no common measure with the subjective experiences of people; in it man had no organic place". ${ }^{11}$ Dante's vision was and should have remained a parable; taken literally it led to thoughts insulated from real emotions, drawing people outside themselves, alienating them from their own depths and crazing them with despair at the meaninglessness of things. It was as though the new wine of the esoteric idea had burst the wine skin of the old mind. Such is the position in which we now find ourselves, thinks Needleman. ${ }^{62}$

Needleman thus accuses Galileo (with Darwin) of being in this way "a principal contributor to modern man's misunderstanding of reality" 63 For the primary function of esoteric ideas, Ideas of the path, as Needleman with allusions to the tariqat calls them, is not directly to organise the world of appearances. ${ }^{64}$ It is rather to search for a new relationship to the thinking process, a new consciousness that interacts with reality immediately through mind, heart and body. ${ }^{65}$ This consciousness needs to be free to relate to thought without being swallowed by the chains of association. Other ways of saying this are that this new consciousness relates only to higher mind, or it becomes itself an organ of perception of the subtle world, or of the Kingdom of Heaven. It is the type of thinking that Ouspensky calls the psychological method, and Gurdjieff 'the Fourth Way'. Such thinking needs to be presented to a different part of the mind from the ordinary rational associative nexus, the automatic psychic processes of ordinary man, as Needleman calls them. Such ideas cannot be understood by that part of the mind that remembers and recombines words and impressions like a computer, ${ }^{66}$ but can only be understood in a certain state of selfawareness. ${ }^{67}$ Needleman cites Gurdjieff to the effect that if symbols intended to be understood by this higher type of thinking are understood only in what Gurdjieff calls a "formatory" fashion, they no longer speak symbolically. ${ }^{68}$ Only with the new mind that mediates a consciousness that can understand reality immediately, "intellectually", rather than through verbal ratiocination, as

\footnotetext{
61 Burkhardt, 'Cosmology and Modern Science' in Needleman (ed) The Sword of Gnosis, 126, 127 .

62 Needleman, $A$ Sense of the Cosmos, 34.

63 Needleman, $A$ Sense of the Cosmos, 72.

64 Needleman, $A$ Sense of the Cosmos, 167.

65 Needleman, $A$ Sense of the Cosmos, 91.

66 Needleman, $A$ Sense of the Cosmos, 117.

67 Needleman, $A$ Sense of the Cosmos, 106.

68 Needleman, $A$ Sense of the Cosmos, 99.
} 
described by Jeanne de Salzmann in The Reality of Being, ${ }^{69}$ can the teaching derived from the path be understood. This type of thinking demands a willingness to undergo a kind of temporary 'derangement' of the logical mind so as to be confronted by the 'vital logic' of natural reality and the corresponding perceptions during those rare moments of symbolic understanding. ${ }^{70}$ Thus though such ideas as the heliocentric theory were true in a pragmatic sense, in that they gratified the isolated rational intellect, the ego and the desires, these scientific interpretations of a "true" in an esoteric sense idea were grabbed by the ego, rendered exoteric and became a pathological and dementing influence upon civilisation. ${ }^{71}$ The new wine of an idea both destroyed the wine skin of the old mind and was itself spilt and spoiled in the process. The desire to manipulate nature moved to centre stage, was empowered by concepts that were but the model of true ideas. ${ }^{72}$

Needleman concedes that modern science has a truth to it that is persuasive, that it organises exoteric perception in a coherent manner for the sake of the human species' survival in the physical world, and that the freedom it affords from the inhumanness of ideas that could not be verified through one's own experience is real. But because the intellectual coup that was the rise of science left out of account the body, a field of force in which the forces of nature must be brought into harmony as servants of consciousness, ${ }^{73}$ the ideas of science could not be universal or unitive at the deepest level; they left humanity again open to the tyranny of the isolated intellect because although they initially showed that thought could be humanised through the senses, this principle was never sufficiently valued, and soon disappeared from science. Although it has to a certain extent reappeared in modern science, there is still no real deepening of the meeting between sensation and thought, no understanding of how universal ideas could be blended into the heart of man through subtler levels of sensation accessible within the framework of the path. The real meaning of unification and the actual source of power or will in a person was never seen in the mainstream of scientific thought. What was needed, what science properly understood should have provided, what the arcane disciplines sought to provide, Needleman says, is that equal working in a person of mind, feelings and body (of Gurdjieff's moving, feeling and intellectual centres, which, as Nicoll

69 De Salzmann The Reality of Being, $5^{8} \mathrm{ff}$.

$70 \quad$ Needleman, $A$ Sense of the Cosmos, 85 .

$71 \quad$ Needleman, $A$ Sense of the Cosmos, 36.

72 Needleman, $A$ Sense of the Cosmos, 170.

73 Needleman, $A$ Sense of the Cosmos, 48. 
says, is the inner aspect of the "Fourth Way"). ${ }^{74}$ For in the body there are finer levels of sensation which, as Nicoll says, afford 'a far more conscious reception of daily life, a far finer perception whose direction is towards both inner and outer.' ${ }^{75}$ These sensations come as life-giving thought that reflects the whole of reality and supports the struggle for self-knowledge, something which cerebral intellect alone cannot do. ${ }^{76}$ But in an attempt to acquire power or will that could only in reality be acquired by understanding the truth taught by the path, by living the "Fourth Way", people have turned through the misunderstanding of esoteric knowledge to thought rather than consciousness. Thus, what could have been a salvific truth, leading to humans with mind, feelings and body in harmony led instead to a world governed unconsciously by the world poison of egoism formed from the emotions un-harmonised and untouched by the intellect, by the ego driven by the passions. In sum, this turning to thought that is modern science represents an abuse and a misunderstanding of the true and real ideas of the path, and their transformation into world poison. ${ }^{77}$

Needleman and Burkhardt both examine also, as noted, Darwin's ideas of evolution and the psychoanalytical movement. But whereas in the earlier examples cited, chemistry coming from alchemy, and the heliocentric view of the solar system, there is no suggestion that miscegenation from esoteric thought led to science that was not on its own terms sound, such is not the case in these later instances, according to these commentators. Here is not the place to go into the detailed criticisms that they offer. Needleman suggests that while Darwin's theory of evolution, an idea, so shocked the mind as to raise serious questions about humanity's place in the universe, rather than bringing a new creative understanding of this, as an idea should, the theory has been tamed, and, as with Galileo's theory, a rational interpretation of it has again driven humanity to the margins of the universe, denying it the crown of creation and seeing people as automatons who operate according to rules invented by the logical mind. The superficial misunderstanding of these symbols of nature which the rational science of biology is confirms in us the meaningless violence and self-deception of our own existence, an existence that ancient teachings summed up as 'death' ${ }^{78}$

74 Nicoll, Psychological Commentaries on the Teachings of Gurdjieff and Ouspensky, 233-234.

75 Nicoll, The Mark, 24.

76 Needleman, $A$ Sense of the Cosmos, 81, 82.

77 Needleman, $A$ Sense of the Cosmos, 162-17o passim.

78 Needleman, $A$ Sense of the Cosmos, 64-86 passim. 
There are similarities with modern psychology. Through Freud's philosophy a person is barred from receiving what the higher understanding or "intellect" in a person reaches down and offers, ideas as a help on the path. Whereas sacred disciplines offer a means of destroying the egoistic emotions for the sake of developing consciousness and real moral and emotional force, allowing one to stand above the play of forces that transpires in the body and ride or use it, making it a tool of real will, modern psychology nourishes exactly those automatic egoistic emotions that the teaching of the path seeks to destroy and which stand in the way of this help, masking subtler feelings that bring people into contact with reality through ideas. ${ }^{79}$ Only by reading the symbolisms of nature and the mind, esoteric in nature, with a mind adapted for the purpose, can the unity of body, heart and mind come about that gives man a true idea of his place in the universe. But in both biology and psychology the esoteric has been misread and turned into world poison.

Needleman also suggests that Einstein's ideas, which might have caused a fundamental overturning of people's view of themselves and the universe, leading to an examination of how they think rather than what they think, have instead been "assimilated" into modern thought, have become "Strange Concepts" "80 instead of new ideas. Ouspensky has much the same idea when he says that psychological thinking, which lies at the heart of all real discoveries, does not usually keep for long.

As soon as ideas which have been found and established by the psychological method [by which he means through interpreting esoteric knowledge] have become everybody's property and begin to be looked upon as permanent and accepted they become logical and, in their application to phenomena of a greater size, defective. ${ }^{81}$

Ouspensky quotes Ibsen to the effect that such truths soon outlive themselves and become lies, such "lean and tough ageing truths" offer little nourishment and are responsible for the moral scurvy which is the life of the people around us. ${ }^{82}$ But if even all this seems more like an unfortunate missed opportunity, the most explosive view of the situation is presented by Needleman in a citation from Ouspensky. ${ }^{83}$ Talking of the Sphinx, Ouspensky suggests that the break-

79 Needleman, $A$ Sense of the Cosmos, 118.

8o Needleman, $A$ Sense of the Cosmos, 92.

81 Ouspensky, A New Model of the Universe, xi.

82 Ouspensky, A New Model of the Universe, xi.

83 Ouspensky, A New Model of the Universe, 136-137. Needleman, A Sense of the Cosmos, 137. 
ing of the ritual of initiation in the Mysteries, the equivalent of the magician invoking spirits he cannot control, represents allegorically man's position visa-vis new ideas that are too strong for him and for which he is unprepared. In legends representing this situation the unprepared are consumed by the sacred fire or die because they see the god. The Sphinx represents a barrier, a protection for and from ideas of a certain order, riddles which man may not approach unless he knows how to answer them. Coming into contact with such ideas a man may not turn back; he cannot go back to living as he once did, but must go farther or perish under the burden of these new ideas which, appearing unexpectedly, are of a terrible power and danger. ${ }^{84}$ In the light of this citation it is easy to see that Einstein's and Heisenberg's ideas are indeed ideas, but of a terrible power and danger. Who can really believe that mankind is in a position other than that of the sorcerer's apprentice who, having unleashed these esoteric things but having only crude and exoteric ideas about them, can neither control or harness them, nor, like Pandora, put them back in the box?

Gruesome enough though this vision of the sorcerer's apprentices may be there is a yet-more-heinous example of misappropriation of the knowledge of the path. Needleman points out the Sufi distinction between Religion (Shariat) and the Path (Tariqat). According to this view 'Religion' is such exoteric aspects as worship, ethics, holy war, charity and the like, while 'the Path', as the Sufi master says, is the seeking of the essence of the forms dealt with in Religion, the investigation of them, the purifying of the heart, and general inner purification. Although exoteric Religion has a part to play in organising the external world to lift people out of barbarism, its essence can only be found through esoteric understanding; only within controlled conditions of the path can the elements of exoteric Religion function both as a support for people to lead a civilised worldly life and also support the struggle for psychological evolution that is the concern of the Path. But

the "esoteric" or inner path embedded within every traditional culture is discoverable only by those yearning for something inexplicably beyond the duties and satisfactions of religious, moral and social life, and moreover this yearning has to be undertaken solely for its own sake, without recognisable psychological motivation. ${ }^{85}$

$84 \quad$ Needleman, $A$ Sense of the Cosmos, 37.

85 Needleman, $A$ Sense of the Cosmos, 113. 
Though there can be no question that exoteric Religion derived from misunderstanding and abuse of the esoteric knowledge of the Path did indeed lead to the amelioration of incipient barbarism to which humanity is prone, this civilising influence came at a price. Christianity is now proving impotent even at holding us back from barbarism. Needleman asks whether it was ever effective at doing this, and whether the utilitarian concepts of Religion (as opposed to esoteric ideas) can ever stabilise the communal life of mankind other than as the direct result of the movement towards inner unity that esoteric knowledge calls for. ${ }^{86}$

The literal misunderstanding of the Gospel truths in the service of a demotic social revolution, the ethos of which was no part of early 'Christianity', destroyed very early in Christianity's history the meaning and the beauty of the esoteric teaching. Was not the formation of the Great Church a catastrophic turning away from the discipline of the path, an abuse and misunderstanding of knowledge meant to remain within that discipline, a catastrophe just as baleful in import as the rise of science? Both Nicoll and Ouspensky see the almost universal degradation of all Religions that follows their initial period of success as an inevitable process of Tariqat giving way to Shariat. Did not the general broadcast of the Gospels, originally written for an esoteric group, cause the Church to become that

Pyramid of Imposture, reared by Rome, All of cement, for an eternal home[?] ${ }^{87}$

What Now?

At the end of A Sense of the Cosmos Needleman offers the only solution that has always been on offer. We have to create the conditions in ourselves in which we can understand the knowledge of the path, by introducing Mind into our own inner world by the harmonisation of the moving, emotional and intellectual centres in ourselves through living the "fourth way". As Gerald Massey says, in another part of the poem quoted above, only "when the prison of the Immortal, Mind, Hath fallen to set free the bound and blind" 88 will our bodies become what they always were and are, an arena for the play of the forces of the

86 Needleman, $A$ Sense of the Cosmos, $166-167$.

87 Massey, The Historical Jesus and the Mythical Christ, 25.

88 Massey, The Historical Jesus and the Mythical Christ, 25. 
cosmos that impinge on us. ${ }^{89}$ Our destiny is to master these forces. Unless we do this we are lost. But knowledge of how to do this remains esoteric, available only to those who prepare themselves for it by creating in themselves a new mind. Only when we attract to ourselves these universal energies by means of a form of attention which the "Fourth Way" seeks to inculcate can we experience that cosmic love which Needleman defines as 'existing in the form of ideas and men who embody and communicate these ideas'. ${ }^{90}$ But even so we are 'speaking of something upon which depends the individual and collective future of mankind'.91 Needleman renders this poetically by saying that such esoteric knowledge lies behind a door made up of the great traditions of civilisation, the other side of which stretches the long path of self-knowledge, which means that what is nectar behind this door, esoteric knowledge rightly understood as the means of healing the soul, is poison this side of it, the world poison of esoteric knowledge misunderstood and utilised for worldly egoistical purposes. The door needs to be guarded, as it was in earlier times (but imperfectly) and the knowledge kept secret; but our modern age, which insists on giving everything to everybody regardless, has no idea of the danger of knowledge without the necessary level of being to support it and takes no notice of door-keepers. Fools rush in where angels fear to tread, repeating the abuse of knowledge of the path. Needleman signs off his book by asking what it means that these door-keepers seem to have vanished in the present age. Is this yet one more sign of the collapse of civilisation? Whether there is any possibility of squaring the circle of bringing esoteric knowledge to the many without its being spoiled and turned into poison, and whether this might be the solution to the world's problems, he does not say.

For Ouspensky rescue from the collapse caused by the

masses of humanity, peoples and races, lower beings as compared with individual man, [who] can never create anything, although they can destroy on their own account ${ }^{92}$

must lie in reconnecting ourselves with esoteric knowledge. In the absence of any formal organisations that enable us to do this we have to do it through encouraging individual use of the 'psychological method which leads in a very

\footnotetext{
89 Needleman, $A$ Sense of the Cosmos, 102.

$90 \quad$ Needleman, $A$ Sense of the Cosmos, 154, 128.

$91 \quad$ Needleman, $A$ Sense of the Cosmos, 85.

92 Ouspensky, A New Model of the Universe, 55.
} 
definite direction, namely towards the esoteric method: ${ }^{93}$ Ouspensky does not say how this would work in practice to solve the world's problems. But the implication, articulated in his chapter 'Superman' in A New Model of the Universe is that we are in the riddle of the Sphinx confronted by the profound conundrum of how to understand the esoteric idea of the 'Superman', of which Christ is but one exemplar. Ouspensky says of the idea of superman, quoting Nietzsche, that it is the purpose of the whole of history, and gives man the sense of his existence; Superman, a potential within all people, must at times emerge and rise out of the masses of crawling humanity. ${ }^{94}$ The building of the future, the serving of the future, are but symbols, symbols of man's attitude to himself, towards his own present; if it is recognised, as Ouspensky suggests, that all the future is contained within people themselves, it is evident that humanity has to do with superman, for superman is itself. ${ }^{95}$ How this idea is taken determines whether the consequences will be positive or negative. Great possibilities and great dangers are co-existent.

Ability to think is the first necessary stage of initiation into the idea of the superman, which ensures safety in approaching this idea. What does it mean to be able to think? It means to be able to think differently from the way to which we are accustomed, that is to say, to conceive the world in new categories, ${ }^{96}$

by a form of esoteric thinking, a higher mind, called by Ouspensky the psychological or esoteric method, much as the "fourth way" is described by commentators such as Jeanne de Salzmann. Man has to understand as an individual with psychological thought this most significant of all esoteric ideas, the superman. If not understood esoterically then world poison, exemplified by the churches' misunderstanding of the image of the Superman that is Christ, or the abuse of Nietzsche's idea by among others the Nazis, will rule the world egoistically and disastrously, as it now does. If, through the development or evolution of the esoteric idea of the superman in himself, achieved by a new form of thinking, there is a right understanding of this idea, then history will be fulfilled and man will come to the sense of his own existence.

93 Ouspensky, A New Model of the Universe, 66.

94 Ouspensky, A New Model of the Universe, 121, 125.

95 Ouspensky, A New Model of the Universe, 144.

96 Ouspensky, A New Model of the Universe, 146. 
On the basis of the parable of the Wheat and the Tares [Matthew 13:37-43], apropos of which Nicoll suggests that people exposed to esoteric ideas either understand them and embrace the spiritual growth which they demand, in other words become wheat, or they misunderstand them and abuse them for worldly ends, becoming tares, the while the two groups being indistinguishable (the tares [darnel] that grow in and with the wheat are on first coming up indistinguishable from it), Nicoll argues that each religion has its own age, eventually losing force and becoming ineffective; 'there has always been a failure of such teaching in process of time, ${ }^{97}$ Failure is followed by renewal of the truth in another form. Though the aeon of Christianity is dying, the truth, the Word of God, essentially esoteric, is constantly sown 'to lift man beyond his senses' 98 and out of barbarism. At the 'consummation of the age' [Matthew 13:40] those in error, the adherents of the sensuous religion that Christianity has become that now dominates the world, tares, will be "harvested, bundled and cast into the fire' [Matthew 13:30], ${ }^{99}$ while those who follow the truth, "esoteric", "inner", "spiritual" psychologically-understood religion will be 'gathered and stored in a barn' to become the seed corn for the next phase of religious development. R.H. Ward, in a radio review of Nicoll's last two books, ${ }^{100}$ sees them as containing this "ageless truth," written by a 'new man', one who will carry those eternal truths and values beyond destruction and into the age which is to come. Ward says that metanoia, hardly a new doctrine, new only in so far as it was old long before the Christian era, is a hard road involving the death of what you are in favour of what you might become. Only by this change of mind shall we change the world, because, as Nicoll says, it is not from life than a man suffers, but from himself. Nicoll's books underline the crux of the Gospel message, that you shall seek first the Kingdom of God, and his Righteousness [Matthew 6:33, Luke 12:31], which means to live the "Fourth Way", and "these things shall be added unto you," [Matthew 6:33], "these things the nations of the world seek after" [Luke 12:30], meaning the world and a solution to its problems, will be granted to you [Matthew 6:33]. This is the message that will save the world. It has always been known, though hidden esoterically, but hardly listened to, or heeded. There is no other message.

97 Nicoll, The Mark, 183.

98 Nicoll, The Mark, 187.

99 Nicoll, The New Man, 134.

100 Ward, 'A New Interpretation of the Gospels', 247. 


\section{Bibliography}

Burckhardt, Titus, 'Cosmology and Modern Science', in The Sword of Gnosis: Metaphysics, Cosmology, Tradition, Symbolism, ed. Jacob Needleman, London: Arkana 1974, 122-178.

De Salzmann, Jeanne, The Reality of Being: The Fourth Way of Gurdjieff, Boston \& London: Shambala 2011.

Guénon, René, 'Oriental Metaphysics', in The Sword of Gnosis: Metaphysics, Cosmology, Tradition, Symbolism, ed. Jacob Needleman, London: Arkana 1974, 40-56.

Gurdjieff, George I., Beelzebub's Tales to his Grandson: An objectively impartial criticism of the life of man. Third Book, London, Melbourne and Henley: Arkana 1950.

Hanegraaff, Wouter J. 'Esotericism', in Hanegraaff, Wouter J., Antoine Faivre, Roelof van den Broek, and Jean-Pierre Brach (eds), Dictionary of Gnosis \& Western Esotericism, Leiden and Boston: Brill 2004, 336-340.

Massey, Gerald, The Historical Jesus and the Mythical Christ, London: Villa Bordighiera —no date given: modern reprint by Forgotten Books 2017.

Needleman, Jacob A Sense of the Cosmos, London: Arkana 1975.

Needleman, Jacob, Lost Christianity, New York: Doubleday 1980.

Nicoll, Maurice, Living Time and the Integration of the Life, London: Vincent Stuart 1952.

Nicoll, Maurice, Psychological Commentaries on the Teaching of G.I. Gurdjieff and P.D. Ouspensky, 5 Volumes, London: Vincent Stuart 1957.

Nicoll, Maurice, The Mark, London: Stuart \& Watkins 1954.

Nicoll, Maurice, The New Man: The Interpretation of some of the Parables and Miracles of Christ, London: Vincent Stuart 195 .

Ouspensky, Pyotr D., A New Model of the Universe: Principles of the Psychological Method in its Application to Problems of Science, Religion, and Art, Mineola: New York 1931; repr. Dover Publications, 1997.

Segal, Robert A., 'Myth and Ritual' in The Routledge Companion to the Study of Religion, ed. John Hinnells, London and New York: Routledge 2010, 372-396.

Ward, R.H., 'A New Interpretation of the Gospels', in The Listener, 10. February 1955, Volume 50: 242-247. (Broadcast on Sunday, 23 January, 1955 at 5.40 pm [Disc No sLo.69778, recorded 6. Jan '55-unpublished note to this effect in Nicoll Archive, Special Collections, University of Edinburgh])

Webb, James, The Harmonious Circle: The Lives and Work of G.I. Gurdjieff, P.D. Ouspensky, and Their Followers, New York: G.P. Putnam's Sons 1980.

Willmett, John, Maurice Nicoll and the Kingdom of Heaven: a study of the psychological basis of 'esoteric Christianity' as described in Nicoll's writings, University of Edinburgh: $\mathrm{PhD}$ thesis 2017 . 